\title{
Type of Industry Moderates Effects of Environmental Performance and International Sales on Carbon Emissions Disclosure
}

\author{
Etty Murwaningsari ${ }^{1}$, Sistya Rachmawati ${ }^{2}$. \\ \{etty_nasser@yahoo.com ${ }^{1}$, sistya_r@yahoo.com² \\ Trisakti University, Indonesia
}

\begin{abstract}
The purpose of this research is to analyze the effect of environmental performance on carbon emission disclosure, the effect of international sales on carbon emission disclosure, and the type of industry is moderating the effect of environmental performance and international sales on carbon emission disclosures. Unit analysis is manufacturing company with time horizon 5 years (2015-2019). Secondary data obtained from company's annual report, sustainability report, company's website, and Indonesia Stock Exchange's website. Data analysis techniques is Multiple Regression Analysis. Results showed that environmental performance and international sales does not significantly influence carbon emission disclosure. Type of industry is able to moderate the effect of environmental performance on carbon emission disclosure. Type of industry is not able to moderate the effect of international sales on carbon emission disclosure. Control variables which are institutional ownership and independent commissioner significantly influences carbon emission disclosure.
\end{abstract}

Keywords: Environmental Performance; Type of Industry; Carbon Emission Disclosure

\section{Introduction}

Industry is one of the main factors participating in the destruction of nature because the materials used contain various chemical substances and its emissions potentially pollute the air. Therefore, the environmental responsibility report, which includes the emission information disclosure, is one of the industry's efforts to report its business operations in order to explore, control, and protect nature and the environment. The emission disclosure information is expected to help create added value for the entity so that it can continue to sustain its business. Some of industrial sectors such as industry of cement, steel, pulp and paper, textile, ceramics, fertilizer, petrochemical as well as certain food and beverages, contribute large amounts of carbon emissions which caused the encouragement to conduct research on carbon emission disclosure in the manufacturing industry. The company's benefits obtained by discovering carbon emissions is a cost of equity reduction. Investors expect returns in their investment activities in the form of dividends and capital gains, while from the 
company's point of view it is included in the cost of equity. This difference interests can be reduced by signaling greater disclosure of carbon emissions. Kirana states that the better the information conveyed, the smaller the level of risk generated [1]. In accordance with the principle of high risk - high return, then the investment risk is low due to the good news in the form of disclosure of carbon emissions resulting in a company's low cost of equity.

Carbon emissions disclosure is a form of the company's contribution to climate change, especially the global warming. The existence of a business entity is not coming out from society. Therefore, companies must increase the disclosure of carbon emissions in order to gain legitimacy from the community. The research results show there are many factors influence the companies to disclose carbon emissions, including Ermaya \& Apriliana, said the variable of industry's type can affect the level of carbon emissions disclosure. "Companies which are intensive in producing carbon will receive greater pressure from the community and the government compared to companies which are members of non-carbon intensive groups [2]. This will cause companies to be more concerned in disclosing carbon emissions." Deantri et al., found that environmental performance variables can also affect the level of disclosure of carbon emissions [3]. Companies that have good environmental performance will disclose carbon emissions because they can improve the company's image in the community so that the company's operational activities can be legitimized from the community. Gonzalez-Gonzalez \& Ramírez, in their research stated that international sales variables affect the level of disclosure of carbon emissions [4]. Companies that expand their sales internationally will get greater pressure from the countries concerned regarding carbon emissions, especially countries that have signed the Kyoto Protocol. The legitimacy of companies by foreign countries can be threatened if the company fails to meet the information needs related to carbon emissions, so companies with a high percentage of international sales tend to disclose carbon emissions.

Based on the study results, it turned out to give contradictory results, means there are other variables have a contingent effect. In a connection, researchers are motivated to re-examine the study by adding a moderating variable in the form of industry type variables. This refers to the research Apriliani \& Septyan, Pratiwi \& Sari, Choi et al., found the industrial type of variable has a positive influence on the disclosure of carbon emissions [2], [5], [6]. As well as adding control variables in the form of institutional ownership, independent board of commissioners, and audit committee. The importance of including control variables in this study because the control variables have been studied by previous researchers. Therefore, the variables that have been studied need to be included as control variables in this study. This is expected to prevent the existence of a missing variable so it can overcome biased research results. The research objectives are to analyze: (1) The effect of environmental performance on the disclosure of carbon emissions, (2) The effect of international sales on to the disclosure of carbon emissions, (3) the type of industry moderates the effect of environmental performance on the disclosure of carbon emissions, (4) the type of industry which moderates international sales on the disclosure of carbon emissions.

\section{Theory and Hypothesis Development}

"Companies with good environmental performance will provide information to stakeholders with voluntary disclosures about the environment. Companies try to disclose the type of their performance through voluntary disclosures which cannot be easily imitated by companies with poor environmental performance. This can potentially increase the value of the company in the stakeholder's view. 
Based on the "stakeholder theory" the company can show its seriousness in overcoming environmental problems by disclosing carbon emissions which can provide information for stakeholders. Companies with good environmental performance will voluntarily disclose information related to their carbon emissions. Besides being able to meet the demands of stakeholders, disclosure of this information can also add to the good value of the company, so the stakeholders have confidence in the company. The "legitimacy theory" states that companies with good environmental performance will make environmental disclosures because it can improve the company's image in the public' eyes so the company's activities remain legitimized by the community. Environmental disclosure can be used as a means of informing the company's environmental performance to stakeholders [5] (Deantari et al., 2019).

Research results M. Clarkson et al., Dawkins \& Fraas, Ahmadi \& Bouri, (2017), Prafitri \& Zulaikha, Prasetya \& Yulianto and Deantari et al., found that the environmental performance variable has a positive effect on the disclosure of carbon emissions [3], [7]-[11]. Based on the description above, the proposed hypothesis is:

H1 : Environmental Performance Has a Positive Effect on Disclosure of Carbon Emissions

Indonesia is a country that has ratified the Kyoto Protocol. This makes companies in Indonesia that expand their international sales will be under great pressure related to their activities in generating carbon emissions. Therefore, companies that make international sales will disclose information about carbon emissions in order to gain the trust and legitimacy of the country concerned.

According to Gonzalez \& Ramirez international sales have a positive effect on the disclosure of carbon emissions. This is due to greater encouragement and pressure by the countries concerned [4]. So, companies respond to this pressure by disclosing positive information about resource users and processes during the production of their products to enhance the company's positive image in the eyes of the international community. Based on the description above, the proposed hypothesis is:

H2 : International Sales Have a Positive Effect on Disclosure of Carbon Emissions

Not all companies in various fields disclose their activities. The company will not disclose its environmental activities if it does not have a positive value for the company itself. Industrial companies that have an impact on the environment tend to disclose their environmental responsibilities, including the disclosure of carbon emissions. This is done by the company as a responsibility for its operating activities. So that the company will still have legitimacy in the eyes of the community. High profile companies such as those in mining and manufacturing produce higher and severe environmental damage and carbon emissions compared to low profile companies such as those engaged in services, trade, and others Cahya, $[12]$.

According to Pratiwi, "the type of industry has a positive and significant effect on carbon emission disclosures [13]. Disclosure of carbon emissions is greater in companies in industries that have incentives to produce emissions such as energy, transportation, materials, and utilities. Vice versa". The results of research Apriliani \& Septyan, Pratiwi \& Sari, Choi et al., found that the industrial type of variable had a positive influence on the disclosure of carbon emissions [2], [5], [6]. Based on the description above, the proposed hypothesis is:

H3: Type of Industry strengthens the influence of environmental performance on Disclosure of Carbon Emissions

Not all companies in all fields disclose their activities. The company will not disclose its environmental activities if it does not have a positive value for the company itself. Industrial companies that have an impact on the environment will disclose more about their 
environmental responsibilities, including the disclosure of carbon emissions. This is done by the company as a responsibility for its operating activities, so that the company still gets legitimacy in the eyes of the community.

High-profile companies such as mining and manufacturing produce crews' environmental claims and carbon emissions are more severe than low profile companies such as services, trade, and others. According to Pratiwi, the type of industry has a positive and significant effect on carbon emission disclosures [13]. Disclosure of carbon emissions is greater in industrial companies with incentives to generate emissions such as energy, transportation, materials, and utilities. Vice versa. The results of the research Apriliana \& Septyan, Pratiwi, Choi et al., "found the industrial type of variable has a positive effect on the disclosure of carbon emission [2], [6], [13]. Based on the description above, the proposed hypothesis is:

H4 : The type of industry strengthens the effect of international sales on the disclosure of carbon emissions.

\section{Research Method}

\subsection{Research Design}

The unit of analysis in this research is a manufacturing company. The research sample amounted to 29 companies during the 2015 - 2019 period, thus the number of observations was 145 . The data used in this study is secondary data obtained from the company's annual report. Company sustainability report, company website, and the IDX website "(Indonesian Stock Exchange)." The statistical test tool used is Multiple Linear Regression Analysis.

\subsection{Definition of Variables and Measurement}

\subsubsection{Dependent Variable}

\section{Carbon Emissions Disclosure}

The measurement of carbon emission disclosure variables in this study uses the checklist method developed by Choi et al., obtained from the request sheet developed by CDP "(Carbon Disclosure Project)" [6]. This checklist method is used to determine which disclosures are made by companies about climate change and carbon emissions to the public. There are five categories of checklist methods with 18 items that can be identified by researchers. Each item in the measurement of the company's carbon emissions disclosure will be given a score of 1 . On the other hand, companies that do not make disclosures according to the category will be given a score of 0 . After collecting the number of scores revealed by the company. The score results will be entered in the formula used Choi et al., [6]. With the formula:

$\mathrm{CED}=\sum \mathrm{Di} / \mathrm{M}$

Note: CED : Carbon Emissions Disclosure, $\sum D i$ : Total score disclosed by the company, $M:$ Total items in the carbon emission disclosure index (18 items) 


\subsubsection{Independent Variable}

\section{a) Environmental Performance}

"Environmental performance is the company's ability to create a clean and green environment. This ability can see how much responsibility the company has to the environment. Measurement of environmental performance variables refers to research [4] Ermaya \& Apriliana, which is measured by PROPER". Environmental performance assessment through PROPER is carried out by giving a score from the proxied rank with numbers 5 to 1 [2]. The PROPER rating is divided into 5 color ratings, namely: Gold rating (Excellent) score 5, green rating (good) score 4, blue rating (fair) score 3, red rating (poor) score 2 , black rating (very bad) score 1 .

\section{b) International Sales}

International sales are how much international sales by the company to the company's total sales. The measurement of the international sales variable refers to the research Stanny \& Ely, which is measured by the following formula:

$\mathrm{PI}=$ International sales/Total sales X 100\% [14]

\subsubsection{Moderating Variables}

\section{Industry Type}

Industry type is an industrial group which is divided into two categories, namely nonintensive industry in producing carbon emissions and intensive industry in producing carbon emissions. measuring industry type with dummy variable. The measurement of industrial type variables refers to research Jannah \& Muid [15]. Industries that are included in the category of incentives that generate carbon emissions include energy, transportation, raw materials and utilities based on the Global Industry Classification Standard (GICS) which are high profile types, which are given a score of 1 , while non-incentive industries in producing carbon are given a score of 0 which are low profile types.

\subsubsection{Control Variable}

\section{a) Institutional Ownership}

"Institutional ownership is the number of shares owned by an institution or organization. Institutional ownership is measured by the percentage of the number of shares owned by the institutional party divided by the total number of outstanding shares of the company. The measurement of institutional ownership variables following formula:

$\mathrm{KI}=$ Number of institutional shares/Number of outstanding shares $\mathrm{X} 100 \%$ 


\section{b) Independent Board of Commissioners}

"The independent board of commissioners is an unaffiliated board of commissioners with the company. This measurement refers to research Amaliyah \& Solikhah, with the following formula:

DKI $=$ Number of independent commissioners/Number of commissioners X 100\% [16].

\section{c) Audit Committee}

"The audit committee is the company's chosen committee to assist the commissioners in carrying out the supervisory function on the company's performance. The measurement of this variable refers to research Amaliyah \& Solikhak, which is measured based on its effectiveness, namely the number of audit committee meetings in a year".

$\mathrm{KA}=\sum$ Audit committee meeting in 1 year [16]

\subsection{Population and Sample}

The research population is a manufacturing company, the sampling technique uses purposive sampling, namely the sample must meet the required criteria, namely: (1) Manufacturing companies listed on the Indonesia Stock Exchange and consisted of publish annual reports and sustainability reports in 2015-2019, (2) Manufacturing companies that consistently disclose emissions i carbon, PROPER rating, international sales in 2015-2019.

\subsection{Data analysis method}

Hypothesis testing using multiple regression analysis model with SPSS version 22.0 software. The multiple regression equation used is as follows:

$$
\begin{aligned}
\mathrm{PEK}= & \mathrm{q}+\beta 1 \mathrm{KL}+\beta 2 \mathrm{PI}+\beta 3 \mathrm{KL} * \mathrm{TI}+\beta 4 \mathrm{PI}^{*} \mathrm{TI}+\beta 5 \mathrm{KM}+\beta 6 \mathrm{KI}+ \\
& \beta 7 \mathrm{DKI}+\beta 8 \mathrm{KA}+\mathrm{e}
\end{aligned}
$$

Note: PEK: Disclosure of Carbon Emissions; IT : Industrial Type; KL : Environmental Performance; KM : Managerial Performance; KI : Institutional Performance; DKI : Independent Board of Commissioners; KA : Audit Committee; PI : International Sales; e : Error term.

\section{Results and Discussion}

\subsection{Descriptive statistics}

Table 1 is a descriptive statistic, as follows:

Table 1. Descriptive Statistics Test Results

\begin{tabular}{ccccc}
\hline Variable & Min & Max & Mean & Deviation Std. \\
\hline Carbon Emissions Disclosure & 0.0600 & 0.7200 & 0.1396 & 0.1351 \\
\hline
\end{tabular}




\begin{tabular}{|c|c|c|c|c|c|}
\hline $\begin{array}{c}\text { Variable } \\
\end{array}$ & & Min & Max & Mean & Deviation Std. \\
\hline Environmental Performance & & 0.4000 & 1.0000 & 0.6418 & 0.1295 \\
\hline International Sales & & 0.0000 & 100.0000 & 30.2099 & 30.1230 \\
\hline Institutional Ownership & & 0.4100 & 99.2400 & 66.2319 & 24.7261 \\
\hline $\begin{array}{l}\text { Independent } \quad \text { Board } \\
\text { Commissioners }\end{array}$ & of & 0.0000 & 80.0000 & 38.8724 & 10.0892 \\
\hline Audit Committee & & 3.0000 & 53.0000 & 7.4206 & 5.0949 \\
\hline
\end{tabular}

In table 1 above, it is known that the disclosure variables of carbon emissions, environmental performance, international sales, and control variables, namely institutional ownership, independent commissioners, audit committees have an average value greater than the standard deviation value, meaning that the research data is homogeneous.

Table 2. Frequency Descriptive Statistics Test Results

\begin{tabular}{|c|c|c|c|c|c|}
\hline \multicolumn{2}{|c|}{ Variable } & Frequency & Percent & Valid Percent & Cumulative Percent \\
\hline \multirow[t]{2}{*}{ TIPE } & low profile & 27 & 18.4 & 18.4 & 18.4 \\
\hline & high profile & 118 & 81.6 & 81.6 & 81.6 \\
\hline
\end{tabular}

In this study, there is one moderating variable, namely Industrial Type, which is an industrial group which is divided into two categories, namely non-intensive industries in producing carbon emissions and intensive industries in producing carbon emissions. type of industry is measured by a dummy variable. The measurement of industrial type variables refers to research Jannah \& Muid, [15]. Industries that are included in the intensive category that produce carbon emissions include energy, transportation, raw materials and utilities based on the Global Industry Classification Standard (GICS) which are high profile types and are given a score of 1 , while non-intensive industries in producing carbon are given a score of 0 which are low profile types. $27(18.4 \%)$ samples were companies categorized as "Low Profile" carbon emissions and $118(81.6 \%)$ companies were categorized as "High Profile" carbon emissions.

\subsection{Classic Assumption Test}

The method used in this study is Ordinary Least Square where if we use this method to answer the problem then there are several assumptions that must be met or commonly referred to as the classical assumption test, which consists of error normality, multicollinearity, heteroscedasticity and heteroscedasticity.

Table 3. Classic Assumption Test Results

\begin{tabular}{cccc}
\hline \multirow{2}{*}{ Variable } & Multicollinearity Test & Heteroscedasticity Test & Conclusion \\
\cline { 2 - 3 } & VIF & Sig & \\
\hline KL & 7.023 & 0.073 & Ho failed to reject \\
PI & 5.957 & 0.423 & Ho failed to reject \\
TIPE & 39.902 & 0.172 & Ho rejected \\
KL*TIPE & 42.544 & 0.096 & Ho rejected \\
PI*TIPE & 7.168 & 0.252 & Ho failed to reject \\
KI & 1.112 & 0.060 & Ho failed to reject \\
DKI & 1.013 & 0.074 & Ho failed to reject \\
KA & 1.281 & 0.263 & Ho failed to reject \\
\hline
\end{tabular}




\begin{tabular}{cccc}
\hline Variable & Multicollinearity Test & Heteroscedasticity Test & Conclusion \\
\cline { 2 - 3 } & VIF & Sig & \\
\hline Kolmogorov Smirnov & 0,057 & & Ho rejected \\
Durbin Watson & 1,989 & Ho failed to reject \\
\hline
\end{tabular}

$\mathrm{PEK}=\mathrm{q}+\beta 1 \mathrm{KL}+\beta 2 \mathrm{PI}+\beta 3 \mathrm{KL} * \mathrm{TI}+\beta 4 \mathrm{PI} * \mathrm{TI}+\beta 5 \mathrm{KM}+$

$\beta 6 \mathrm{KI}+\beta 7 \mathrm{DKI}+\beta 8 \mathrm{KA}+\mathrm{e}$

Note: KL : Environmental Performance; PI : International Sales; TYPE : Industrial Type; KI : International Ownership; DKI : Independent Board of Commissioners; KA : Audit Committee.

Based on the results of normality testing using the Kolmogorov Smirnov analysis tool, the asymp sig value of 0.057 is greater than 0.05 , then Ho is rejected and it is concluded that the normality distribution for the error variable is fulfilled. The results of the multicollinearity test using the inflation factor varian analysis tool showed that the VIF value for all variables in this study was less than 10 , so Ho failed to be rejected and it was concluded that the independent variables were not correlated with each other or the assumption of no multicollinearity was met, except for the interaction variable between KL*TYPE and TYPE. According to Gary, et al, that the multicollinearity test is not needed in the multiple moderated regression (MMR) model [17]. The multicollinearity test is only seen when the research model is additive regression analysis.

Based on the results of heteroscedasticity testing using the glacier test analysis tool, it is known that the sig value for all variables in this study has a value greater than $0.05(5 \%)$ then Ho fails to be rejected and it is concluded that the assumption of homoscedasticity is fulfilled. The results of the autocorrelation test using the Durbin Watson Test analysis tool, showed that the DWstat value was 1.989 , then Ho failed to be rejected and it was concluded that the assumption of no autocorrelation was fulfilled.

\subsection{Individual Hypothesis Test (t Test)}

Table 4. Test Results With Moderation

\begin{tabular}{cccccc}
\hline Variable & Prediction & \multicolumn{3}{c}{ With Moderation } & Conclusion \\
\cline { 3 - 5 } & & $\begin{array}{c}\text { Coef } \\
\text { Ficient }\end{array}$ & $\begin{array}{c}\text { Std. } \\
\text { Error }\end{array}$ & Prob & \\
\hline Konstanta & & 4.183 & 2.765 & 0.131 & \\
KL & + & 0.030 & 0.039 & 0.448 & Ha rejected \\
PI & + & 0.010 & 0.014 & 0.477 & Ha rejected \\
TIPE & & 9.749 & 2.739 & $0.000^{*}$ & Ha accepted \\
KL*TIPE & & 0.183 & 0.041 & $0.000^{*}$ & Ha accepted \\
PI*TIPE & & -0.003 & 0.016 & 0.868 & Ha rejected \\
KI & $+/-$ & -0.037 & 0.007 & $0.000^{*}$ & Ha accepted \\
DKI & $+/-$ & 0.076 & 0.018 & $0.000^{*}$ & Ha accepted \\
KA & $+/-$ & 0.122 & 0.040 & 0.365 & Ha rejected \\
Adjust R2 & & & & 0,458 & \\
F stat & & & & 0.000 & \\
\hline & & & & &
\end{tabular}




\subsection{Discussion of Research Results}

\subsubsection{Effect of Environmental Performance on Disclosure of Carbon Emissions}

The results of environmental performance testing on carbon emission disclosures show a sig value of $0.448 / 2>0.05$ (alpha $5 \%$ ), so Ho fails to be rejected. It was concluded statistically at the $95 \%$ confidence level that there was no positive effect of Environmental Performance on Disclosure of Carbon Emissions. These results do not support research Deantari et al. which found that environmental performance had a positive and significant effect on the disclosure of carbon emissions [3]. The inconsistency of the results of this study may be due to the company's poor environmental performance so that it does not affect the disclosure of carbon emissions.

The results of this study do not support the stakeholder theory where the disclosure of carbon emissions is one of the company's efforts to meet stakeholder demands. Companies can demonstrate their responsibility to address the environment by disclosing carbon emissions. Companies with good environmental performance tend to voluntarily disclose information related to their carbon emissions. These results also do not support the signaling theory where companies that disclose carbon emissions provide a positive signal for investors. The existence of this carbon emission disclosure can assist investors in understanding the company's responsibility to the environment so that it can assist investors in making investment decisions.

\subsubsection{Effect of International Sales on Carbon Emission Disclosure}

The results of international sales research on carbon emission disclosures show a sig value of $0.477 / 2>0.05$ (alpha 5\%), then Ho is accepted. It was concluded statistically at the 95\% confidence level that there was no effect of International Sales on Disclosure of Carbon Emissions. These results do not support research Gonzalez and Ramírez that international sales have a significant positive effect on the disclosure of carbon emissions [4]. This shows that the greater the level of international sales made by the company, the higher the disclosure of carbon emissions will be. Companies that make international sales tend to be under greater pressure and supervision related to the disclosure of company information related to their activities, including information on carbon emissions. The pressure for disclosure of carbon emissions is greater in countries that have ratified the Kyoto Protocol, of which Indonesia is a member. The inconsistency of the results of this study may be due to the fact that companies in Indonesia that make international sales tend not to disclose their carbon emissions. Thus, this study cannot prove the proposed hypothesis.

\subsubsection{Industry type moderates the effect of environmental performance on carbon emission disclosure}

The results of the industrial type research moderate the effect of environmental performance on the disclosure of carbon emissions showing a sig value of $0.000<0.05$ (alpha $5 \%$ ), so Ho is rejected. It is concluded that the type of industry strengthens the positive influence of environmental performance on the disclosure of carbon emissions. The results show that environmental performance has no effect on the disclosure of carbon emissions. According to Baron \& Kenny, precisely when $\mathrm{X}$ is not significant to $\mathrm{Y}$, it is necessary to have 
a moderating variable [18]. Variable $\mathrm{X}$ cannot be a single predictor, if there is no moderating variable. Variable $\mathrm{X}$ will affect $\mathrm{Y}$ if there is a moderating variable.

The results of research Apriliani \& Septyan, Pratiwi \& Sari (2016), Choi et al., found that the industrial type variable had a positive influence on the disclosure of carbon emissions [2], [5], [19]. From the results of this study when referring to Sharma, et all namely the moderating variable (Industrial Type) has significant results while the interaction variable (TYPE * KL) also has significant results, the moderating variable is included in the category of pseudo moderation (Quasi Moderators) [20]. Quasi moderation is a variable that moderates the relationship between the independent variable and the dependent variable which is also the independent variable.

\subsubsection{Industry type moderates the effect of international sales on carbon emission disclosure}

The results of the industrial type test moderating the effect of international sales on carbon emission disclosures show a negative beta sign meaning that it is not in accordance with the hypothesis proposed in this study, therefore the significance test was not continued and Ho failed to be rejected. It is concluded that the type of industry is not able to strengthen international sales of the disclosure of carbon emissions. The results showed that international sales as measured by the ratio of the company's international sales to the company's total sales had no effect on the disclosure of carbon emissions. According to Baron \& Kenny, precisely when $\mathrm{X}$ is not significant to $\mathrm{Y}$, it is necessary to have a moderating variable [18]. Variable $\mathrm{X}$ cannot be a single predictor, if there is no moderating variable. Variable $\mathrm{X}$ will affect $\mathrm{Y}$ if there is a moderating variable.

The results of research Apriliani \& Septyan, Pratiwi \& Sari, Choi et al., found that the industrial type variable had a positive influence on the disclosure of carbon emissions [2], [5], [19]. From the results of this study, when referring to Sharma et al., namely the industrial type moderating variable has significant results while the interaction variable (TYPE * PI) does not have significant results, the moderating variable is included in the Moderation Predictor category [20]. This means that this moderating variable only acts as a predictor (independent) variable in the relationship model that is formed.

\subsubsection{Effect of control variable on carbon emission disclosure}

The results show that institutional ownership has a negative effect on the disclosure of carbon emissions, meaning that the smaller the institutional ownership, the greater the disclosure of carbon emissions. These results support the research of Halimah and Yanto [21]. While the independent board of commissioners variable has a positive influence on the disclosure of carbon emissions. These results support the research Fernandes et al. which means that the greater the proportion of the company's independent commissioners, the company will disclose carbon emissions more broadly [22]. The independent board of commissioners is an external party to the company that has the task of supervising the company, supervision by an independent commissioner is optimal because the number of independent commissioners is increasing so that they are able to influence the company's decision to disclose carbon emissions. The audit committee variable is not proven to have an effect on the disclosure of carbon emissions. The inability of the audit committee to influence the disclosure of carbon emissions may be due to the dominance of votes from members of the 
audit committee who think that the disclosure of carbon emissions has no effect on the company. This is because the disclosure of carbon emissions is a form of voluntary disclosure.

\section{Conclusions}

The results of this study indicate that the effect of environmental performance and international sales on carbon emissions is not proven to be significant. According to Baron \& Kenny, precisely when $\mathrm{X}$ is not significant to $\mathrm{Y}$, it is necessary to have a moderating variable [18]. Variable $\mathrm{X}$ cannot be a single predictor, if there is no moderating variable. Variable $\mathrm{X}$ will affect $Y$ if there is a moderating variable.

The type of industry is proven to strengthen the effect of environmental performance on the disclosure of carbon emissions. When referring to Sharma, et all, namely the Industrial Type moderating variable has significant results while the interaction variable (TYPE*KL) also has significant results, the moderating variable is included in the pseudo-moderation category (Quasi Moderator) [20]. Quasi moderation is a variable that moderates the relationship between the independent variable and the dependent variable which is also the independent variable.

The type of industry is not proven to strengthen the effect of international sales on the disclosure of carbon emissions. When referring to Sharma et al., the moderating variable (Industrial Type) has significant results while the interaction variable (TYPE*PI) does not have significant results, the moderating variable is included in the Moderation Predictor category (Variable Moderating Predictor) [20]. This means that this moderating variable only acts as a predictor variable (independent) in the relationship model that is formed. Meanwhile, the control variables, namely institutional ownership and independent board of commissioners, are proven to have a significant influence on the disclosure of carbon emissions.

\section{Implications and Suggestions}

The theoretical implication is that it is expected to increase insight and knowledge for academics, especially regarding the factors that affect the disclosure of carbon emissions. Investors are expected to be able to add new information for investors regarding environmental disclosures made by the company. Suggestions for further research include

adding a sample of banking financial services companies, so that the research results can be generalized.

\section{References}

[1] P. A. Kirana, "Pengaruh Kualitas Audit Terhadap Cost Of Equity Capital," Skripsi Strata-1. Universitas Diponegoro., 2013.

[2] H. N. L. Ermaya dan E. Apriliana, "Pengaruh Tipe Industri, Kinerja Lingkungan, Dan Profitabilitas Terhadap Carbon Emission Disclosure," Widyakala J., vol. 6, no. 1, hal. 84-95, 2019.

[3] S. A. O. Deantari, M. Pinasti, dan E. Herwiyanti, "Faktor-Faktor Yang Mempengaruhi Pengungkapan Emisi Gas Rumah Kaca Dari Perspektif Akuntansi Hijau,” Equilib. J. Ekon. Syariah, vol. 7, no. 1, hal. 88-11, 2019. 
[4] J. M. Gonzalez-Gonzalez dan C. Zamora Ramírez, "Voluntary carbon disclosure by Spanish companies: an empirical analysis," Int. J. Clim. Chang. Strateg. Manag., vol. 8, no. 1, hal. 57-79, Jan 2016, doi: 10.1108/IJCCSM-09-2014-0114.

[5] C. Pratiwi, P. dan F. Sari, V., "Pengaruh Tipe Industri Media Explosure dan Profitabilitas Terhadap Carbon Emission Disclosure," J. WRA, vol. 4, no. 2, hal. 829844, 2016.

[6] B. B. Choi, D. Lee, dan J. Psaros, "An analysis of Australian Company Carbon Emission Disclosures," Pacific Account. Rev., vol. 25, no. 1, hal. 58-79, 2013.

[7] P. M. Clarkson, Y. Li, G. D. Richardson, dan lorin P. Vasvari, "Revisiting the relation between environmental performance and environmental disclosure: An empirical analysis," Accounting, Organ. Soc., vol. 33, no. 4-5, hal. 303-327, 2008.

[8] C. Dawkins dan J. W. Fraas, "Coming clean: The impact of environmental performance and visibility on corporate climate change disclosure," J. Bus. ethics, vol. 100, no. 2, hal. 303-322, 2011.

[9] A. Ahmadi dan A. Bouri, "The relationship between financial attributes, environmental performance and environmental disclosure," Manag. Environ. Qual. An Int. J., vol. 28, no. 4, hal. 490-506, Jan 2017, doi: 10.1108/MEQ-07-2015-0132.

[10] A. Prafitri dan Zulaikha, "Analisis Pengungkapan Emisi Gas Rumah Kaca," J. Akunt. Audit., vol. 13, no. 2, hal. 155-175, 2016.

[11] R. A. Prasetya dan A. Yulianto, "Analysis of Factors Affecting the Disclosure of Corporate Carbon Emission In Indonesia," J. Din. Akunt., vol. 10, no. 1, hal. 71-81, 2018.

[12] B. Cahya, "Carbon Emission Disclosure: Ditinjau Dari Media Exposure, Kinerja Lingkungan Dan Karakteristik Perusahaan Go Public Berbasis Syariah Di Indonesia," Nizham, vol. 5, no. 2, 2016.

[13] P. C. Pratiwi, Pengaruh Tipe Industru, Media Exposure, dan Profitabilitas terhadap Carbon Emission Disclosure. Padang: Universitas Negeri Padang, 2016.

[14] E. Stanny dan K. Ely, "Corporate environmental disclosures about the effects of climate change," Corp. Soc. Responsib. Environ. Manag., vol. 15, no. 6, hal. 338-348, 2008.

[15] R. Jannah dan D. Muid, “Analisis faktor - faktor yang mempengaruhi Carbon Emission Disclosure pada Perusahaan Indonesia,” J. Account., vol. 3, no. 2, hal. 1, 2014.

[16] I. Amaliyah dan B. Solikhah, "Pengaruh Kinerja Lingkungan dan Karakteristik Corporate Governance Terhadap Pengungkapan Emisi Karbon," J. Econ. Manag. Account. Technol., vol. 2, no. 2, hal. 129-141, 2019.

[17] G. H. McClelland, J. R. Irwin, D. Disatnik, dan L. Sivan, "Multicollinearity is a red herring in the search for moderator variables: A guide to interpreting moderated multiple regression models and a critique of Iacobucci, Schneider, Popovich, and Bakamitsos (2016)," Behav. Res. Methods, vol. 49, no. 1, hal. 394-402, 2017.

[18] R. M. Baron dan D. A. Kenny, "The Moderator-Mediator Variable Distinction in Social Psychological Research: Conceptual, Strategic, and Statistical Considerations," J. Pers. Soc. Psychol., vol. 51, hal. 1173-1182, 1986.

[19] B. Bae Choi, D. Lee, dan J. Psaros, "An analysis of Australian company carbon emission disclosures," Pacific Account. Rev., vol. 25, no. 1, hal. 58-79, Jan 2013, doi: $10.1108 / 01140581311318968$.

[20] S. Sharma, R. M. Durand, dan O. Gur-Arie, "Identification and analysis of moderator variables," J. Mark. Res., vol. 18, no. 3, hal. 291-300, 1981.

[21] N. Halimah dan H. Yanto, "Determinant of Carbon Emission Disclosure at Mining 
Companies Listed in Indonesia Stock Exchange," in International Conference on Economics, Business and Economic Education 2018 Volume 2018, 2018, hal. 127-141.

[22] S. M. Fernandes, A. C. Bornia, dan L. R. Nakamura, "The influence of boards of directors on environmental disclosure," Manag. Decis., vol. 57, no. 9, hal. 2358-2382, Jan 2019, doi: 10.1108/MD-11-2017-1084. 